\title{
STRATEGI PEMASARAN LEMBAGA AMIL ZAKAT NAHWA NUR UNTUK MENINGKATKAN DONATUR DI MASA PANDEMI COVID-19 DI CIBINONG, BOGOR, JAWA BARAT
}

\author{
Dewi Nari Ratih Permada, Ugeng Budi Haryoko, Enny Savitri, Agus Supriatna, \\ Didi Sunardi \\ Fakultas Ekonomi Universitas Pamulang \\ Email:dosen00821@unpam.ac.id
}

\begin{abstract}
The Covid-19 pandemic in Indonesia began with the discovery of sufferers of Covid-19 on March 2, 2020. The social and economic side of the covid19 pandemic has also felt the impact of the pandemic. As a result, many people cannot work because of the government's appeal to stay at home. The Covid-19 pandemic is slowly eating away at the joints of the people's economy. Especially in the Parung Panjang area, Bogor. The village area of Parung Panjang has very minimal income or can be said to have no income because they cannot leave the house.The purpose of this PKM activity is to improve the marketing strategy of the Nahwa Nur Amil Zakat Institute, located at Ruko Sabar Ganda, Jl. KSR Dadi Kusmayadi No.6, Cibinong, Bogor, West Java so that donations will continue to increase during the Covid-19 pandemic. Participation in providing solutions to solve partner problems, namely the poor in the Parung Panjang Bogor area because of the Covid-19 Pandemic, namely they did not get income due to the PSBB which was enforced in the West Java region. From that basis, the lecturers of Pamulang University, especially the Management Study Program in collaboration with the Nahwa Nur Amil Zakat Institute, are trying to ease their burden by learning and providing donations in the form of food (groceries) which are distributed to several places for people affected by the Covid-19 pandem in the Cibinong area, Bogor, West Java.
\end{abstract}

Keywords: PKM, Marketing Strategy, Amil Zakat Nahwa Nur Institution, Donors during the Covid-19 Pandemic

\begin{abstract}
Abstrak
Pandemi covid-19 di Indonesia diawali dengan temuan penderita penyakit covid-19 pada 2 Maret 2020. Dampak pandemi covid-19 turut dirasakan masyarakat dari sisi sosial dan ekonom. Imbasnya, banyak masyarakat tidak bisa bekerja karena adanya imbauan untuk tetap di rumah dari pemerintah. Pandemi Covid-19 perlahan menggerogoti sendi-sendi perekonomian rakyat. Menyusul, pemerintah membatasi ruang aktivitas dan kerumunan warganya. Dan kondisi ini berimbas pada kaum dhuafa. Terutama di Daerah Parung panjang, Bogor. Wilayah perkampungan Parung Panjang berpenghasilan sangat minim atau bisa dikatakan tidak memiliki penghasilan disebabkan tidak dapat keluar rumah. Tujuan dari kegiatan PKM ini adalah untuk meningkatkan strategi pemasaran Lembaga Amil
\end{abstract}


Zakat Nahwa Nur yang berlokasi di Ruko Sabar Ganda, Jl. KSR Dadi Kusmayadi No.6, Cibinong, Bogor, Jawa Barat agar donasi terus bertambah selama pandemi Covid-19. Partisipasi dalam memberikan solusi untuk menyelesaikan masalah mitra yaitu masyarakat miskin di kawasan Parung Panjang Bogor akibat Pandemi Covid-19 yaitu tidak mendapatkan penghasilan akibat PSBB yang diberlakukan di wilayah Jawa Barat. Atas dasar itulah para dosen Universitas Pamulang khususnya Program Studi Manajemen bekerjasama dengan Lembaga Nahwa Nur Amil Zakat berusaha meringankan bebannya dengan belajar dan memberikan santunan berupa sembako (sembako) yang disalurkan ke beberapa tempat. untuk orang yang terkena pandem Covid-19 di kawasan Cibinong, Bogor, Jawa Barat.

Kata Kunci: PKM, Strategi Pemasaran, Lembaga Amil Zakat Nahwa Nur, Donatur di Masa Pandemi Covid-19

\section{A. PENDAhULUAN}

Telah dua bulan berlalu kita mengalami musibah wabah corona virus desease 2019 (Covid-19) dimana hal ini mempengaruhi semua aspek kehidupan seperti kesehatan, pendidikan, ekonomi, agama, dan sosial dan politik. Pemerintah menetapkan pandemic Covid-19 sebagai pandemi global. Untuk itu pemerintah pusat dan daerah harus segera bertindak untuk menanggulangi pandemi global ini secara serentak. Tak terkecuali anggota masyarakat yang tidak memiliki kekuatan ekonomi yang stabil seperti anak yatim, anak asuh, pedagang kecil, para supir taksi, para ojek, keluarga-keluarga kurang mampu sangat merasakan dampak dari wabah Covid-19 ini.

Sosialisasi yang kurang optimal dari pihak pemerintah terhadap virus ini menyebabkan hampir di seluruh dunia terinfeksi virus Covid-19. Selain itu, masyarakat yang kurang sadar akan pentingnya menjaga kesehatan dan kebersihan Kurangnya sosialisasi Pedoman Pencegahan dan Pengendalian Covid-19 kepada masyarakat, sehingga banyak yang tidak mengetahui bahwa dirinya adalah Orang Dalam Pemantauan (ODP), Pasien dalam Pengawasan (PDP) dan Suspek dan mereka merasa sehat dan masih keluar kota dan keluar negeri, tanpa disadari sudah membawa virus Covid-19. Masih banyak juga masyarakat yang tidak mentaati peraturan pemerintah untuk di rumah saja menjadi bagian penyebab kenaikan penularan yang terjadi hampir di 200 negara.

Hal ini pula menyebabkan banyak Pemimpin Pemerintah Daerah yang melakukan Lockdown di daerahnya masing-masing untuk mengurangi penularan virus tersebut. Oleh karena itu, Pemerintah Daerah mengajukan Pembatasan Sosial Berskala Besar (PSBB) yang diajukan kepada Menteri Kesehatan yang diatur dalam Undang-Undang No. 6 Tahun 2018 tentang Karantina Kesehatan dan sesuai dengan Keputusan Presiden Republik Indonesia Nomor 11 Tahun 2020 tentang Penetapan Kedaruratan Kesehatan Masyarakat Corona Virus Desease 2019 (Covid-19).

Berdasarkan atas Undang-Undang dan Peraturan Pemerintah tersebut, beberapa Pemimpin Daerah yang meningkat penyebaran Covid-19 mengajukan PSBB ke kementerian Kesehatan. Pada tanggal 7 April 2020 Kementerian Kesehatan mengeluarkan Surat Keputusan Menteri Kesehatan Republik Indonesia Nomor HK.01/07/MENKES/239/2020 tentang Penetapan Pembatasan Sosial Berskala Besar di Wilayah Provinsi DKI Jakarta Dalam Rangka Percepatan Penanganan Corona Virus Disease 2019 (COVID-19). Setelah dikeluarkan SK Menkes tersebut Gubernur DKI Jakarta mulai menerapkan PSBB di wilayah 
DKI Jakarta dari tanggal 10 April 2020 sampai dengan tanggal 23 April 2020. Apabila dalam waktu 14 hari tidak ada penurunan maka dapat diperpanjang lagi selama 14 hari berikutnya.

Kebijakan tersebut diikuti beberapa Provinsi lainnya seperti Banten dan Jawa Barat. Pemerintah Provinsi Jawa Barat mengeluarkan Peraturan Gubernur tentang pedoman pelaksanaan Pembatasan Sosial Berskala Besar (PSBB) yang berlaku untuk Bogor, Depok, Bekasi atau Bodebek dimulai dari tanggal 15 April 2020 dan disoalisasikan dimulai tanggal 13 - 14 April 2020. Peraturan Gubernur Nomoe 27 tahun 2020 tentang Pedoman PSBB dalam penanganan Coronavirus Disease atau Covid-19 di Bodebek, isinya mengatur pembatasn di sektor pendidikan, tempat kerja, fasilitas umum dan ibadah, kegiatan budaya sampai moda transportasi, dan disebut paling akhir ini, termasuk penggunaan kendaraan pribadi, hingga protap angkutan roda dua berbasis online.

Sebagai dosen yang mempunyai amanah Tri Dharma Perguruan Tinggi sangat ingin membantu Pemerintah Republik Indonesia untuk mengatasi dampak Covid-19 ini ke masyarakat kurang mampu. Melalui kegiatan PKM (Pengabdian kepada Masyarakat) ini kami coba membantu dlam lingkup yang lebih kecil yaitu kepada Lembaga Amil Zakat (LAZ) Nahwa Nur yang berlokasi di Ruko Sabar Ganda, Jl. KSR Dadi Kusmayadi No.6, Cibinong, Bogor, Jawa Barat.

Kegiatan PKM ini sangatlah ditunggu-tunggu oleh masyarakat, bukan hanya sumbangan materi namun sumbangan ilmu pengetahuan yang dapat meningkatkan kinerja dari LAZ Nahwa Nur itu sendiri. Kami yakin walaupun kiprah PKM ini dalam lingkup yang terbatas namun implikasi dari kegiatan ini bisa luar biasa. Kegiatan shadaqoh adalah bagian pembelajaran penting bagi umat manusia jika mereka berfikir. Banyak sekali manfaat dari shadaqoh antara lain seperti yang kita ketahui dalam hadits berbunyi, "Tidaklah sedekah itu mengurangi harta." (HR. Muslim); Dari Abu Umamah r.a., Nabi saw. bersabda, "Wahai anak Adam, seandainya engkau berikan kelebihan dari hartamu, yang demikian itu lebih baik bagimu. Dan seandainya engkau kikir, yang demikian itu buruk bagimu. Menyimpan sekadar untuk keperluan tidaklah dicela, dan dahulukanlah orang yang menjadi tanggung jawabmu." (Muslim); "Wahai Rasulullah, sedekah yang mana yang lebih besar pahalanya?" Beliau menjawab, "Engkau bersedekah pada saat kamu masih sehat, saat kamu takut menjadi fakir, dan saat kamu berangan-angan menjadi kaya. Dan janganlah engkau menunda-nunda sedekah itu, hingga apabila nyawamu telah sampai di tenggorokan, kamu baru berkata, "Untuk si fulan sekian dan untuk fulan sekian, dan harta itu sudah menjadi hak si fulan" (Muttafaqun 'alaih. HR. Bukhari no. 1419 dan Muslim no. 1032).

Untuk itu PKM ini pula sebagai pembelajaran dosen dan tenaga pendidik lain agar dapat memaknai arti berbagi, berbagi bukan hanya materi namun berbagi ilmu yang bermanfaat sehingga kiprah kita sebagai dosen dan tenaga pendidik benar-benar dirasakan oleh masyarakat sekitar atau masyarakat umum.

Pelaksanaan dimulai tanggal 6 Mei sampai dengan 8 Mei 2020 yang berlokasi di di Ruko Sabar Ganda, Jl. KSR Dadi Kusmayadi No.6, Cibinong, Bogor, Jawa Barat, Indonesia 


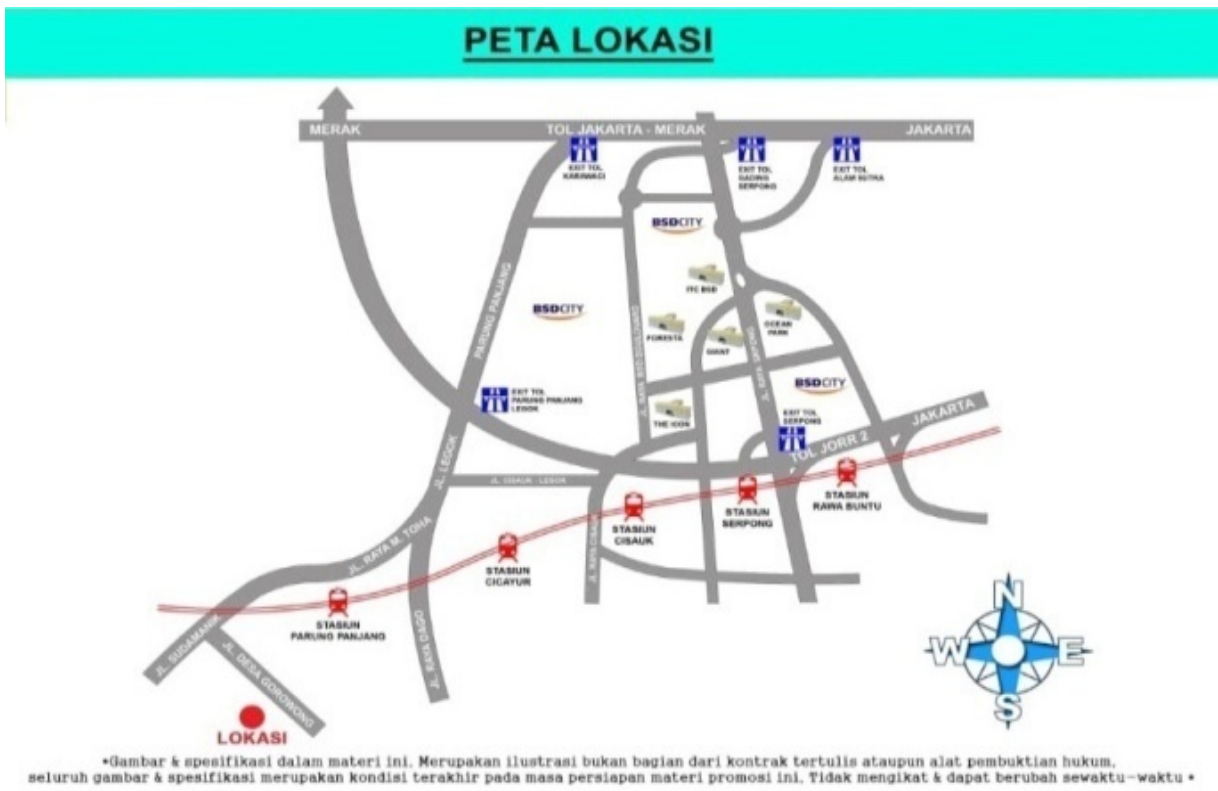

\section{B. METODE PELAKSANAAN KEGIATAN}

Metode kegiatan ini berupa pemberian materi dan wawasan kepada para pengurus atau pengelola Lembaga Amil Zakat Nahwa Nur dengan kondisi saat ini masih menggunakan metode tradisional dimana Lembaga Amil Zakat Nahwa Nur dalam menjaring para donatur bersfiat pasif dan tidak menggunakan media yang lebih mudah dan simpel. Maka solusinya yaitu dengan beberapa strategi yang bisa dicoba untuk mengubah usaha konvensional yang masih mengandalkan cara lama dalam memulai usaha, untuk bisa beradaptasi dengan perkembangan dunia usaha di situasi industri 4.0 saat ini antara lain (jurnal.id, 2019).

Adapun acara tersebut terselenggara dari tanggal 6 sampai dengan 8 Mei 2020 dengan rincian acara sebagai berikut:

1. Hari pertama pengarahan yang diberikan oleh para nasumber dan penyampaian materi kepada pengurus Lembaga Amil Zakat Nahwa Nur.

2. Hari kedua pratek cara efektif pengalangan Donasi dan persiapanan pengeloaan Donasi dengan membuat bentuk paket bingkisan untuk masyarakat yang dilakukan oleh anggota PKM dan pengurus Lembaga Amil Zakat Nahwa Nur.

3. Praktek pendistribusian paket donasi kepada Masyarkat yang dilakukan secara efektif dengan melakukan Protokol kesehatan yang sudah ditentukan dalam masa Pandemi Covid-19.

Beberapa media bisa dimanfaatkan dalam hal operasional Lembaga Amil Zakat, seperti media Instagram, Facebook, Tweeter, dan media online lainnya dengan secara terbuka. Diharapkan dengan tersebarnya informasi melalui media tersebut dapat juga lebih luas jangkauan dalam penjaringan para donatur dan lingkup pekerjaan dari LAZ Nahwa Nur, antara lain :

1. Memanfaatkan Teknologi

Melakukan kegiatan pemasaran dengan memanfaatkan internet atau dapat membuat pembukuan dengan menggunakan komputer dan masih banyak lagi yang lainnya.

2. Gunakan sosial media

Indonesia memiliki banyak pengguna sosial media seperti Twitter, Instagram, Facebook, BBM, Line dan sebagainya. Karena itu sosial media dapat dijadikan alat dalam strategi pemasaran untuk menjaring lebih banyak lagi donatur. 
3. Menggunakan digital marketing

Digital marketing adalah aktivitas promosi sebuah brand atau pun produk/jasa menggunakan media elektronik atau digital.adapun teknik pemasaran dalam digital marketing seperti seacrh engine optimization (SEO), billboard elektronik, iklan televisi dan radio, email marketing dan lainnya.

4. Mobile friendly

Tingginya jumlah pengguna smarthpone dan produk gadget lainnya juga perlu diperhatikan. Perlu menyesuaikan strategi pemasaran dengan tampilan yang mobile friendly. Sehingga akan lebih banyak orang yang melihat aktivitas LAZ Nahwa Nur yang bermanfaat bagi banyak orang.

5. Menggunakan aplikasi

Dengan menggunakan aplikasi bisa menghemat biaya, waktu dan juga tenaga. Selain itu, aplikasi-aplikasi tersebut juga memberikan kenyamanan dalam donatordonaturnya.

6. Inovasi

Seperti yang diketahui bahwa dunia bisnis sangat cepat berubah, hampir setiap harinya ada saja sebuah trend baru. Oleh karena itu, inovasi sangatlah dibutuhkan agar dapat menjaring donator untuk LAZ Nahwa Nur.

7. Memberikan pelayanan terbaik

Tidak ada yang lebih berharga dalam dunia bisnis dibandingkan dengan memenuhi kebutuhan konsumen. Meskipun, dalam dunia digital Anda juga harus memberikan pelayanan terbaik kepada donatur Anda.

\section{HASIL DAN PEMBAHASAN}

Setelah mendapatkan informasi dari hasil survey yang kami lakukan melalui wawancara melalui daring maka kami langsung membuat kelompok dalam membantu kesulitan LAZ Nahwa Nur tersebut. Adapun tahapan-tahapan yang kami lakukan dalam Pengabdian Kepada Masyarakat ini diantaranya sebagai berikut:

1. Tahap Persiapan:

Kami melakukan survey kepada LAZ Nahwa Nur yang menggalang dana untuk masyarakat yang membutuhkan. Setelah kami mendapatkan data masyarakat kurang mampu diperkampungan yang membutuhkan bantuan dikarenakan tidak mendapatkan penghasilan. Hal ini disebabkan karena tidak boleh melakukan kegiatan di luar rumah dan mereka tidak memiliki alat komunikasi yang memadai untuk melakukan pembelajaran daring.

Setelah survey dilakukan maka ditentukan lokasi pelaksanaan dan sasaran yang benar-benar membutuhkan bantuan.

2. Tahap Pelaksanaan

Tahap ini kami memberikan donasi kepada LAZ Nahwa Nur untuk didistribusikan kepada masyarakat ang tidak mampu yang tekena Dampak Covid-19 dan bantuan tersebut dibelikan sembako yang mereka butuhkan. Melalui media sosial, dana yang terkumpul kami berikan dan diserahkan melalui transfer ke rekening LAZ Nahwa Nur dan langsung dibelikan oleh LAZ Nahwa Nur untuk segera didistribusikan kepada yang membutuhkan.

Tahap pemberikan materi mengenai Strategi pemasaran guna meningkatkan donasi selama pandemi Covid-19 akan dilakukan dengan webinar kepada pengurus LAZ Nahwa Nur. 


\section{KESIMPULAN DAN SARAN}

\section{Simpulan}

Pelaksanaan kegiatan Pengabdian Kepada Masyarakat oleh Lembaga Penelitian dan Pengabdian Masyarakat (LPPM) Universitas Pamulang yang dilakukan oleh dosen-dosen program studi manajemen telah berjalan dengan lancar dan mendapat sambutan hangat dari tempat pelaksanaan kegiatan ini yaitu Ketua dan Pengurus pengurus LAZ Nahwa Nur serta masyarakat sekitar Cibinong, Bogor, Jawa Barat.

Pembelajaran peningkatan strategi pemasaran dalam rangka menambah jumlah donator untuk LAZ Nahwa Nur sangat dirasakan manfaatnya baik untuk pengurus maupun untuk masyarakat sekitar. Walaupun ditengah pandemi covid-19 baik dosen prodi Manajemen, Mahasiswa Universitas Pamulang, Pengurus LAZ Nahwa Nur, serta masyarakat sangat antusias terhadap kegiatan PKM ini karena kita saling tolong menolong dalam kebaikan.

Dalam laporan kegiatan ini jauh dari sempurna sehingga tidak menutup kemungkinan kami menerima dengan senang hati masukan demi perbaikan laporan akhir PKM yang semakin baik dan berguna sebagai acuan pelaksanaan PKM selanjutnya untuk dosen dan mahasiswa di lingkungan Universitas Pamulang. Dan Semoga Universitas Pamulang tetap dapat berkiprah lebih baik lagi di masyarakat dalam rangka mencerdaskan kehidupan bangsa di masa mendatang.

\section{Saran}

Berdasarkan hasil kegiatan Pengabdian Kepada Masyarakat, maka kami dari Tim Dosen Universitas Pamulang memberikan saran diantaranya sebagai berikut:

1. Untuk meningkatkan keprofesionalan bagi Pengurus LAZ Nahwa Nur, pembelajaran yang telah disampaikan dapat dipraktek langsung dan untuk memastikan penyampaian pelatihan diterima dengan baik, perlu melakukan evaluasi rutin.

2. Dalam meningkatkan akses pemasaran bagi Pengurus LAZ Nahwa Nur guna meningkatkan donasi selama pandemi covid-19 perlu peran serta pejabat daerah terkait guna lebih mensosialisasikan kegiatan-kegiatan positif dari Lembaga

3. Sebaiknya Pengurus LAZ Nahwa Nur, menjalin kerjasama Pemda dan memanfaatkan media online atau aplikasi online guna memperkenalkan lebih baik ke masyarakat program-program sosialnya.

4. Perlunya kontribusi dari pihak universitas untuk bisa memberikan fasilitas dalam pelayanan kepada masyarakat dalam bentuk sarana dan prasarana setelah adanya pembinaan melalui kegiatan Pengabdian Kepada Masyarakat yang dilakukan oleh dosen dosen nya.

\section{Ucapan Terima Kasih}

Penulis mengucapkan terima kasih yang tak terhingga kepada Ketua Yayasan Sasmita Jaya, LPPM Universitas Pamulang, dan Pihak Pengurus LAZ Nahwa Nur, anggota masyarakat sekitar Lembaga LAZ Nahwa Nur, Rekan-rekan Anggota PKM, Dosen-dosen serta Mahasiswa Universitas Pamulang-Tangerang Selatan yang telah banyak memberikan kontribusi dan dukungan dalam kegiatan PKM ini. Semoga kegiatan ini tetap dinanti masyarakat banyak sehingga Universitas Pamulang yang kita cintai semakin harum namanya di mata masyarakat secara umum, aamiin. 


\section{DAFTAR PUSTAKA}

Al Qur'an Nul Karim, Surat Al-Maidah ayat 2

As Sunnah/Hadits terkait shadaqoh dari HR. Muslim; HR. Bukhari no. 1419 dan Muslim no. 1032.

Jurnal.id (2019, Mare 12). Retrieved from https://www.jurnal.id: https://www.jurnal.id/id/blog/strategi-bisnis-untuk-bersaing-di-era-digital/

Keputusan Presiden Republik IndonesiaNomor 11 tahun 2020 Tentang Penetapan Kedaruratan Kesehatan Masyarakat Corona Virus Disease 2019 (Covid- 19).

Peraturan Pemerintah Republik Indonesia Nomor 21 tahun 2020 Tentang Pembatasan Sosial Berskala Besar Dalam Rangka Percepatan Penanganan Corona Virus Disease 2019 (Covid-19).

Peraturan Menteri Pendidikan Dan Kebudayaan Republik Indonesia Nomor 3 tahun 2020 Tentang Standar Nasional Pendidikan Tinggi.

Peraturan Menteri Pendidikan Dan Kebudayaan Republik Indonesia Nomor 7 Tahun 2020 Tentang Pendirian, Perubahan, Pembubaran Perguruan Tinggi Negeri, Dan Pendirian, Perubahan, Pencabutan Izin Perguruan Tinggi Swasta.

Peraturan Gubernur Nomor 27 Tahun 2020 tentang Pedoman PSBB

Solihin, D. (2020), Mulai Usaha di Masa Pandemi? Ini 'Analisis SWOT' Strateginya. rakyatmerdekanews.com.

Surat Keputusan Menteri Kesehatan Nomor HK.01.07 /Menkes/239/2020, tentang Penetapan Pembatasan Sosial Berskala Besar di Wilayah Provinsi DKI Jakarta Dalam Rangka Percepatan Penanganan Corona Virus Disease 2019 (COVID 19);

Surat Edaran Nomor 2 Tahun 2020 tentang Pencegahan dan Penanganan COVID-19 di Lingkungan Kemendikbud;

Surat Edaran Nomor 3 Tahun 2020 tentang Pencegahan COVID-19 pada Satuan Pendidikan;

Surat Edaran dari Menteri Pendidikan dan Kebudayaan Nomor: 36962/MPK.A/HK/2020 tertanggal 17 Maret 2020 tentang Pembelajaran secara Daring dan Bekerja dari Rumah dalam rangka Pencegahan Penyebaran Corona Virus Disease (Covid-19);

Surat Edaran Nomor: 302/E.E2/KR/2020 tentang Masa Belajar Penyelenggaraan Pendidikan;

Undang-Undang Dasar Negara Republik Indonesia Tahun 1945, Lembaran Negara Republik Indonesia Tahun 1945.

Undang-Undang Nomor 12 Tahun 2012 pasal 1 ayat 9 dikatakan bahwan Tridharma Perguruan Tinggi

Undang-Undang Nomor 6 Tahun 2018 tentang Karantina Kesehatan (Lembaran Negara Republik Indonesia Tahun 2018 Nomor 128, Tambahan Lembaran Negara Republik Indonesia Nomor 6236).

Undang-Undang Nomor 41 Tahun 2004 tentang Wakaf (Lembaran Negara Republik Indonesia Tahun 2004 Nomor 159). 